\begin{abstract}
鎮目 研吾
要旨：発症後 5 時間以内の脳主幹動脈閉塞または狭窄症 8 例に対しウロキナーゼ（以下 UK） を動脈内に投与し，血管撮影，CT，臨床症状，血液所見につき検討を行なった。血管撮影上 4 例 (50\%) に改善がみられ, 症状も 4 例が投与後早期に著明に改善した. 徐々に発症すること の多い血栓症は症状も中等症以下が多く容易に改善し, 塞栓症は重症例が多く効果が得られな い傾向があった．塞栓症の 1 例は再開通に伴い出血性梗塞に移行したが，血腫の形成には至ら ず, 症状も悪化することなく経過した.UK 48万単位を50分間で投与すると, fibrinogen は前値 の34\%， $\alpha_{2}$ anti-plasmin は21\%にまで低下した. UK は数十万 (24 96万) 単位を数十分 ( 1 時 間以内)で投与し, 追加投与や抗凝固剤の併用等は原則として行ならべきでないと考学られる. 本療法は症例を厳密に選択すれば比較的安全で有効な治療法と考兄られる。
\end{abstract}

Key words : cerebral infarction, urokinase, intra-arterial infusion, thrombolysis, arterial occlusion

（脳卒中10：85-93，1988）

はじめに

脳は人体において最も虚血に弱い組織であり, 現在 でも脳梗塞に対する有効な治療法はないと言っても過 言ではない，当初血栓溶解療法はその作用機序から脳 梗塞に対する根本的な治療法ともなりらると考兄ら れ，いくつかの検討が行なわれたが1)2)，1976年の Fletcher 豆の報告以来欧米では殆ど行なわれなくなっ た. しかしこの報告は del Zeppo ら゙) も指摘するごと く, (1) CT が行なわれて拈らず, 脳出血の除外診断が 不充分である，(2）血管閉塞の有無が明らかでない,

（3）140～330万単位と大量を長時間（10～12時間）か けて徐々に投与している，(4) 発症より 6 時間以内の 超急性期例は含まれていない, 等の問題がある。 そこ で我々は以前行った 6 時間点滴静注法でのデータおよ び成績责)も考慮し, 症例を脳組織が ischemic penumbra の状態にあると予想される超急性期症例に限定 し, UK 動注により血行再建を行ない, 脳梗塞への進展 を阻止することを目的に検討を行なった。

浜松医科大学脳神経外科

\section{対象及び方法}

適応は発症後 6 時間以内の虚血性脳血管障害例の5 ち，CTに扔いて低吸收域が存在せず脳血管撮影に打 いて症状に相当する変化が主幹動脈に認められる症例 とした. 血栓症か塞栓症かは問わなかった.UK は血管 撮影中に造影用カテーテルから総䅡又は内頝動脈内に 投与量に応じて10分から50分かけて用手的に注入し た。投与量は， 1 例が 72 万単位で他の 7 例は $24 か ら 48$ 万単位であった。へパリン等抗凝固剂は症例 2 を除き 使用しなかった。血管撮影はUK 投与前と投与直後及 び必要に応じその後にも行なった。

全 8 症例をまとめを表 1 に示す。年齢は 43 歳から 78 歳平均 64.5 歳, 男性 6 例, 女性 2 例であった。血管病 変部位は, 中大脳動脈閉塞 5 例, 同狭窄 1 例, 頭蓋内 内頚動脈閉塞 1 例, 同狭窄 1 例であった。 症例 6,7 , 8 は心房細動を有し症状が突発していることより塞栓 症と診断した。発症よりUK 投与開始までの時間は 2 例の起床時発症型は正確には分からないが， 1 例が 5 時間でその他は 3 時間以内であった。 各症例に対し血 管撮影, CT, 臨床所見の変化について検討するととも に, 症例 6 に関し UK 投与間に内頝動脈より血液を採 取し凝固線溶系の諸因子を測定した。測定項目及び方 


\begin{tabular}{|c|c|c|c|c|c|c|c|c|c|}
\hline 症例 & 年令 & 性別 & 血管病変部位 & $\begin{array}{l}\text { 発症よりUK } \\
\text { 投与までの時間 }\end{array}$ & $\begin{array}{l}\text { UKの } \\
\text { 投与量 }\end{array}$ & 再開通の有無 & $\begin{array}{c}1 \sim 7 \text { 日後の } \\
\text { CT 像 }\end{array}$ & 臨床経過 & $\begin{array}{l}\text { 臨床 } \\
\text { 評価 }\end{array}$ \\
\hline 1. & 43 & 男 & $M_{1} M_{2}$ 閉塞 & $2+\underset{\text { (時間) }}{\alpha}$ & $\begin{array}{c}48 \\
\text { (万単位) }\end{array}$ & 再開通 & & 麻㾝 $4 / 5 \rightarrow 5 / 5$ & 著効 \\
\hline 2. & 52 & 男 & M,閉塞 & 3 & $24+24$ & 再開通 & & 麻㾝 $4 / 5 \rightarrow 5 / 5$ & 著効 \\
\hline 3 & 58 & 男 & IC 狭窄 & 5 & 48 & 狭窄改善 & & 麻瘪 $3 / 5 \rightarrow 5 / 5$ & 著効 \\
\hline 4 & 73 & 男 & $M_{1} M_{2}$ 閉塞 & 2.5 & 36 & 直後は不変 & & 麻㾴 $1 / 5 \rightarrow 5 / 5$ & 著効 \\
\hline 5. & 72 & 女 & M, 狭窄 & 1 & 48 & 狭鿽改員 & & $\begin{array}{c}\text { 麻㾝 } 4 / 5 \rightarrow 0 / 5 \\
\text { (動摇著明) }\end{array}$ & 無効 \\
\hline $6 *$ & 67 & 男 & $M_{1} M_{2}$ 閉塞 & 3 & 72 & $\begin{array}{c}\text { 部分開通 } \\
\text { （後に完全開通） }\end{array}$ & & 麻㾝 $0 / 5 \rightarrow 1 / 5$ & 無効 \\
\hline $7 *$ & 73 & 女 & IC 閉塞 & $2.5+\alpha$ & 48 & 不変 & & 麻㾴 $1 / 5 \rightarrow$ 不変 & 無効 \\
\hline $8 .^{*}$ & 78 & 男 & $\mathrm{M}_{1} \mathrm{M}_{2}$ 閉塞 & 2 & 36 & 不変 & & 麻㾝 $2 / 5 \rightarrow$ 不变 & 無効 \\
\hline
\end{tabular}

測定項目

Urokinase (UK)

tissue-plasminogen activator ( $t$-PA)

FDP

$\alpha_{2}$ antiplasmin $\left(\alpha_{2} \mathrm{AP}\right)$

$\alpha_{2}$ AP-plasmin complex

Fibrinogen ( $\mathrm{fg}$ )

Plasminogen (plg)

Plasminogen activator activity (PA activity)

測定方法

EIA (Enzyme Immunoassay)

EIA

EIA

EIA

EIA

SRID (Single radial immunodiffusion)

SRID

Hydrolysis of S-2251
法は以下の通りである.

\section{結果}

1. 血管撮影及び CT 所見

症例 $1,2 ， 3,5$ は UK 投与直後に再開通ないし狭 窄の著明な改善が見られ，有効と考号られた。症例 6 は UK 投与直後は部分再開通で 2 日後に完全開通を 確認したもので, やや有効と考光られた。症例 4 はUK 投与直後は変化は見られなかったが，主症状の四肢麻 疸が 1 日で筋力 $1 / 5$ から $5 / 5$ と著明に改善していること から, 血管撮影後の早い時期に再開通が起こったと推 察される.症例 7，8 は無効であった. CT では症例 2， 3 は比較的小さな低吸収域, $1,4,5$ は中等度, 6,7 , 8 は中大脳動脈領域に及ぶ低吸収域が出現した。この 万ち症例 6 は mass effectを伴う出血性梗塞となった が，いわゆる漏出性のもので血腫の形成には至らな かった。

\section{2. 臨床所見}

全症例に四肢麻痷が見られ, 症例 $3,5,8$ は失語を 伴っていた. 症状の経過は $1,2,3,4$ が著明な改善を 
示したのに対し $5,6,7,8$ は無効であった。尚症例 5 は狭窄の改善が見られ症状も一時軽快したが再閉塞 のために悪化したと考えられる。血管撮影上改善が見 られた症例中にも症状の経過には相違があった。一般 に軽症（症例 1,2 ）中等症例（症例 3 ） は短時間の内 に改善を示したが，重症例は著効を呈する例(症例 4) と回復の思わしくない例（症例 6 ）が存在した.

\section{3. 血液所見}

図 1 に示すように UK 血中濃度は投与量の増加と ともに上昇し, 最終 48 万単位投与の時点で約 $6.3 \mathrm{U} / \mathrm{m} l$ に達している。これに伴い plasminogen activator 活
性も著明に増加している. plasmin を特異的に阻害す る $\alpha_{2}$ anti-plasmin (以下 $\alpha_{2} \mathrm{AP}=\alpha_{2}$ plasmin inhibitor) は活性のある，free $\alpha_{2} \mathrm{AP} か ゙$ 約 $21 \%$ にな゙低下してい る. 血清 FDP 值は最高 $160 \mathrm{mg} / \mathrm{d} l$ に増加しているが, これは血栓溶解によるものと fibrinogenの分解産物 (いわゆる FgDP)の双方を反映しているものと考兄ら れる. fibrinogen は前値の約34\%にまで低下している. plasminogen は殆ど減少していないが plasmin も同 じ抗原性を持つために同時に測定されていると思われ る.

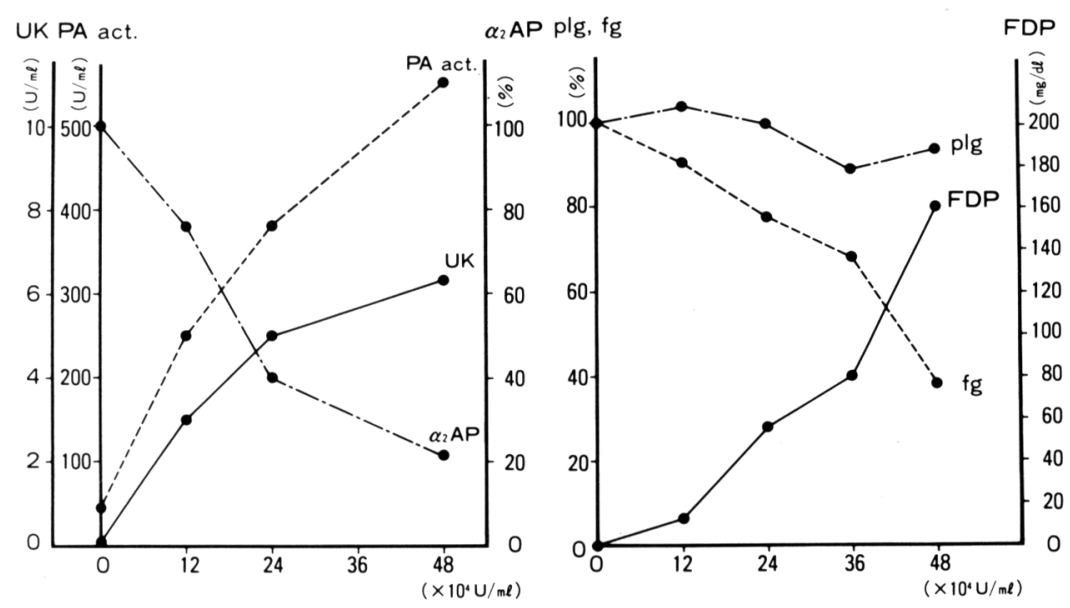

図 1 症例 6 に打ける凝固線溶諸因子の変動。横軸はUK 投与量, 縦軸はそれぞれの 項目の血中濃度あるいは UK 投与前値を100とした時のパーセントを示す。
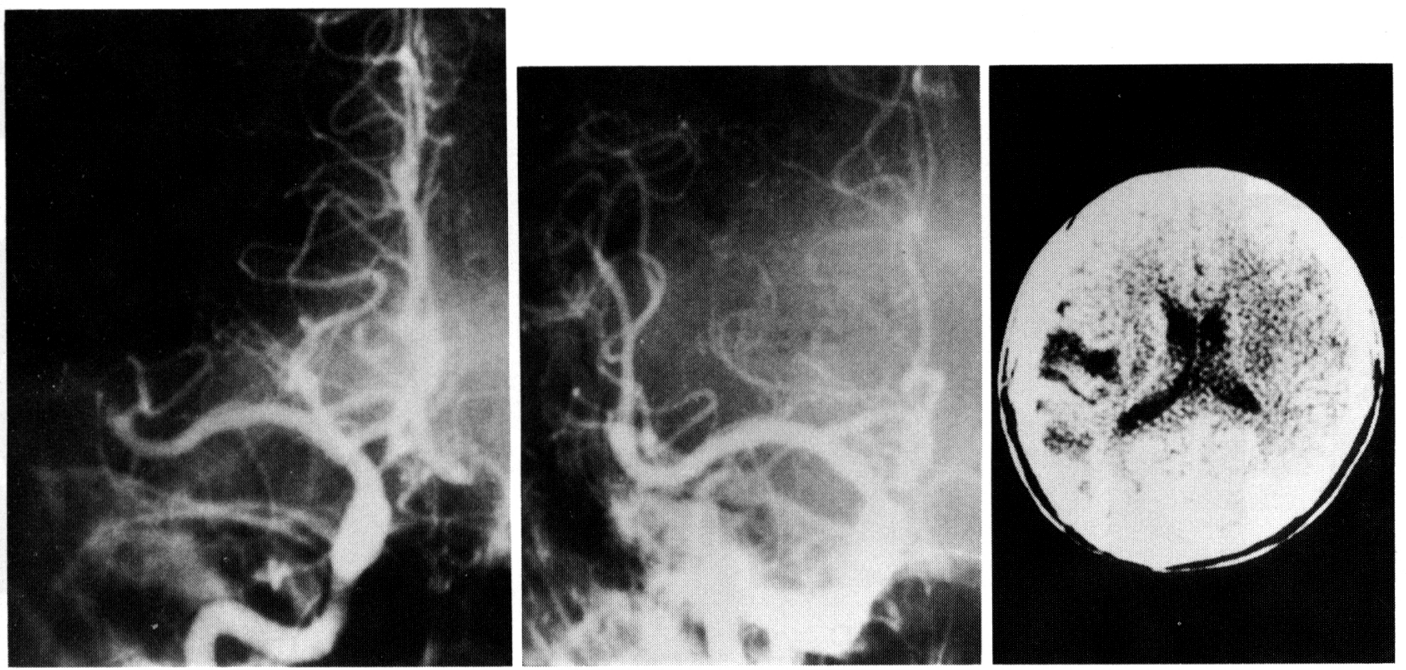

図 $2 U K$ 投与前後の右䅡動脈撮影前後像と 2 週間後の CT 像（症例 1 ） 


\section{症例}

症例 $1 ： 43$ 歳男性. 起床時左片麻痺に気付き来院. 患側の筋力は $4 / 5$, 血管撮影では中大脳動脈分岐部に閉 塞あり一分枝の久造影された。 UK 48万単位投与にて 発症 2 時間余後に再開通が得られ，症状も当日より改 善し全く症状なく退院となった（図 2 ).

症例 $2: 52$ 歳男性. 約 10 分間の TIA 発作が 4 回あっ た翌日，右片麻㽻（筋力 $4 / 5$ ) が改善せず来院した。中 大脳動脈水平部の閉塞は，3 時間後の UK 24 万単位投 与にて再開通を見たが著明な狭窄が残存したためさら に24万単位追加し, 再閉塞予防のため $5,000 \mathrm{U} /$ day の ヘパリンを 3 日間投与した(図 3 ). STA-MCA 吻合術
の適応も検討されたが側副血行が豊富であったため抗 血小板剂の投与を行ない経過観察を行なっている.

症例 3 : 58歳男性. 右片麻瘏, 失語が徐々に出現し 約 4 時間後に来院. 筇力は $3 / 5$, 失語は全失語であった。 5 時間後の血管撮影にて $\mathrm{C}_{1}, \mathrm{C}_{2}$ 部の 2 箇所に狭窄が見 られ，斜位撮影にて円形の陰影欠損が認められた（図 4 ). UK 24万単位動注を行ならと直後に狭窄は著明に 改善し（図 5 ）, 陰影欠損の原因は血栓と考光られた。 CT では頭頂葉に小さな低吸収域が出現したが，麻疩， 失語は著明に改善し計算力低下の及残存した。

症例 $6: 67$ 歳男性. 仕事中に突然倒孔約30分後に来 院. dynamic CT では患側中大脳動脈領域の血流は著 明に減少して扮り，いわゆる absent pattern を示して
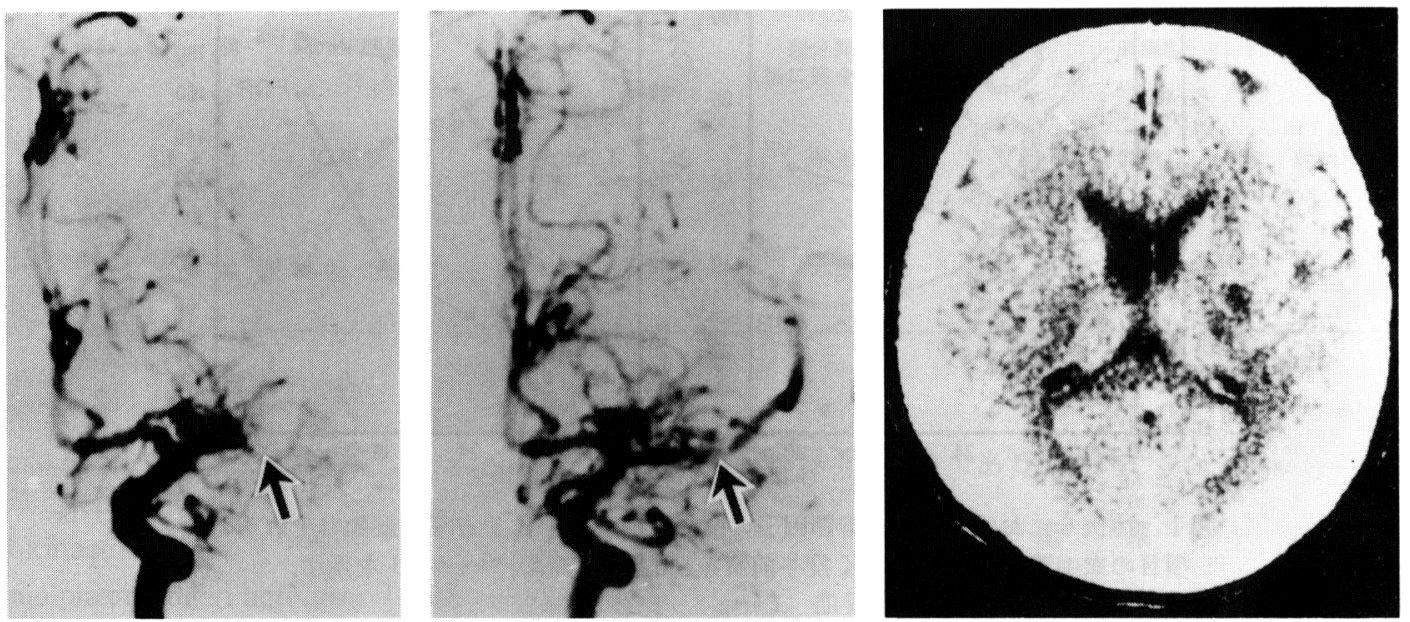

図 $3 \mathrm{UK}$ 投与前後の左頝動脈撮影前後像と 2 日後の CT 像（症例 2)

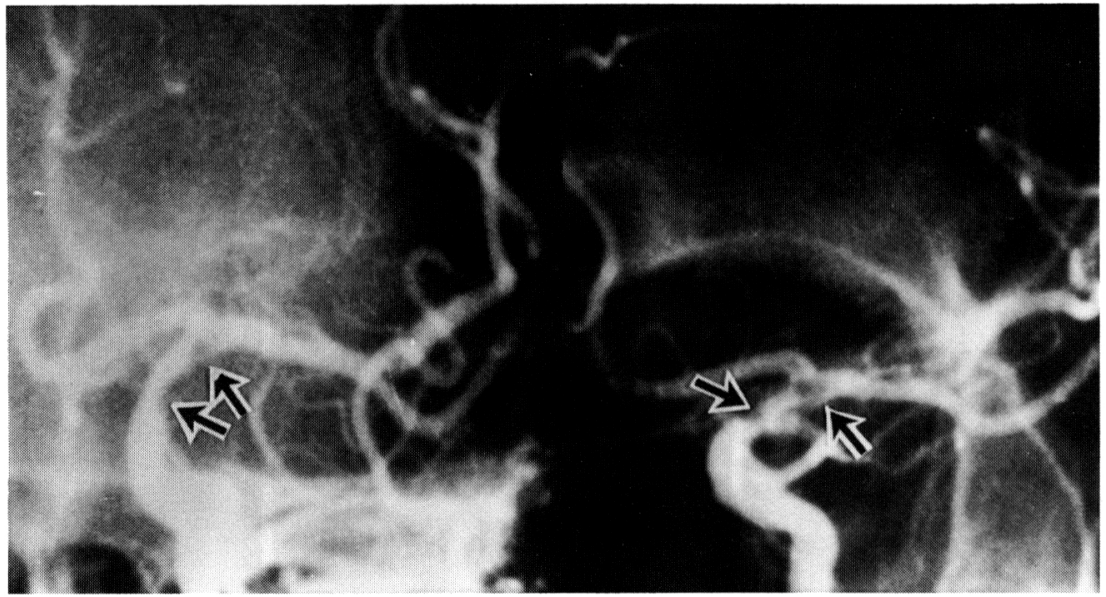

図 $4 \mathrm{UK}$ 投与前の左䅡動脈撮影前後像と同斜位像（症例 3 ） 
いた，MRIでは $\mathrm{T}_{2}$ 強調画像に扒いて内包付近が僅か に high intensity に見られた（図 6 ). 中大脳動脈の閉 塞はUK 72 万単位投与にて一分枝が造影されるよう になり，2 日後に完全再開通が確認された。経時的に
行なわれた $\mathrm{CT}$ 検査では出血性梗塞が明らかとなった が(図 7 ), 症状は悪化することなく経過し約 2 カ月後 に独歩退院となった。
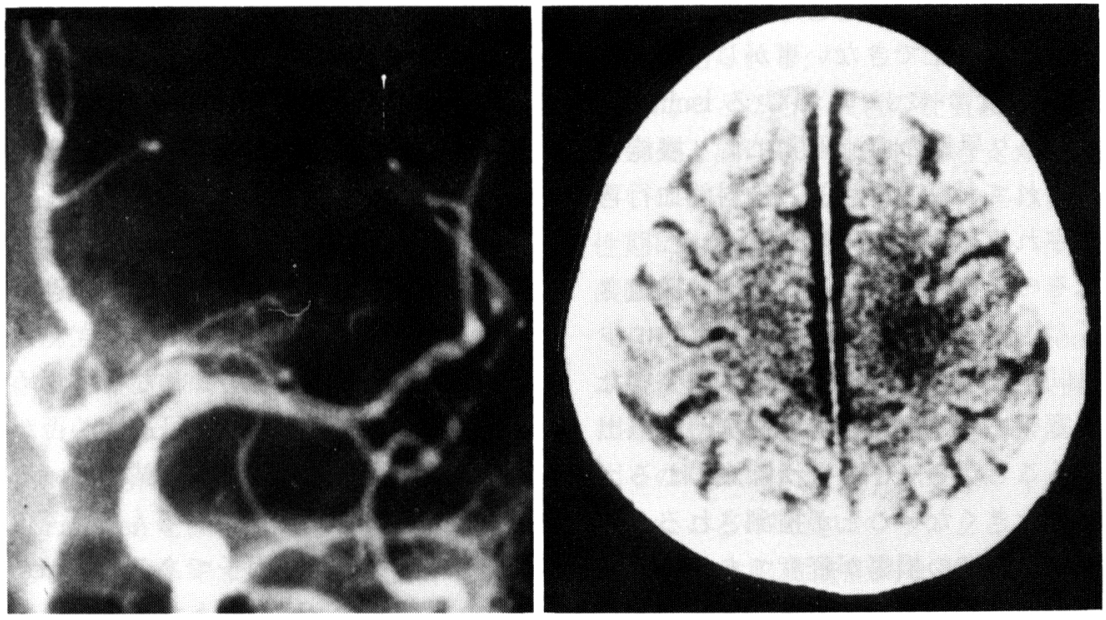

図 $5 \mathrm{UK}$ 投与後の左頝動脈撮影前後像と 2 日後の CT 像（症例 3 ）

\section{$\mathrm{T}_{\text {1強調 }}$}

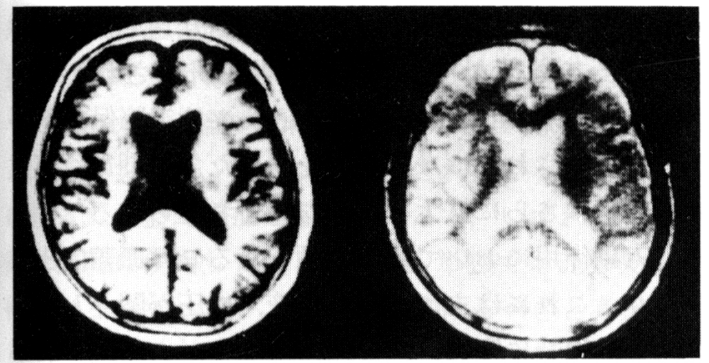

1 時間後

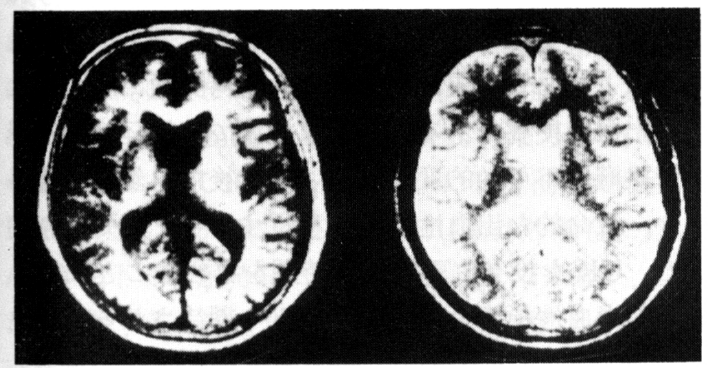

6 時間後

図 6 発症 1,6 時間後の MRI 像（症例 6 )

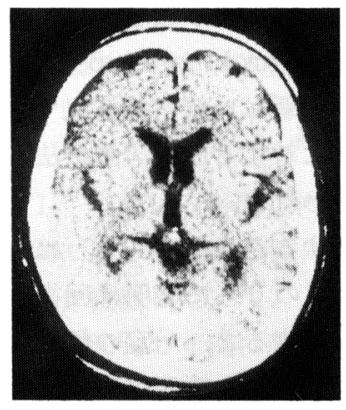

day 0

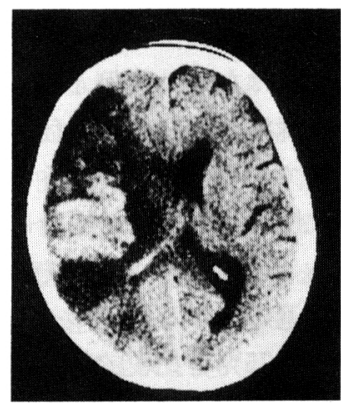

day 4

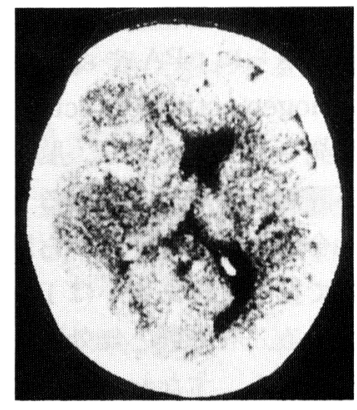

day 1

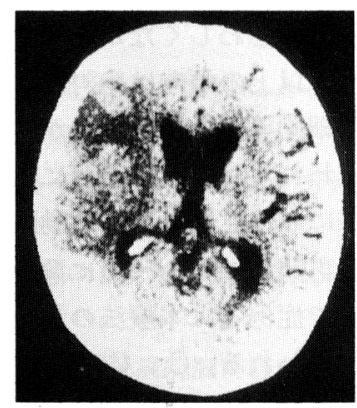

day 20
図 7 症例 6 に打ける CT の経時的変化 


\section{考察}

既に CT 上低吸収域が出現している症例に対して は，抗浮腫剂等二次的な障害を軽減する治療にとどま ることもやむをえないと思われる。しかし発症直後に 来院し CT 上明らかな所見がないのにもかかわらず, その後の低吸収域出現を阻止できない事がしばしばあ り,これらの症例のなかにはいわゆる ischemic penumbra の状態にあり早期の血流再開により機能の 回復する症例も含をれており，外科的，内科的血行再 建術の適応が考慮されるべきと考えられる。

血栓溶解療法はその出血性の副作用のために敬遠さ れ，本邦でも UK は一般に微小循環改善6を目的に少 量（6万単位 7 日間）投与が行なわれているにすぎな い. しかし心筇梗塞等に対する血栓溶解療法時の脳出 血の報告は稀であることから，UK それ自体による出 血の可能性はさほど大きくないことが推測される，虚 血による脳拐よび血管組織の損傷が軽度であれば比較 的安全に行ならことができ，手技も簡単であることか ら外科的療法以前に試みる価值があると思われる。最

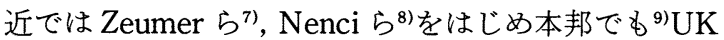
の動脈内投与により著効を呈したといら報告も散見さ れ, さらに t-PA や single-chain urokinase-type plasminogen activator (scu-PA) 等新しい線溶療法剂10) 開発されて来て打り，脳梗塞に対する血栓溶解療法は 再評価の時期に来ていると思われる。

今回の 8 例を症状から評価すると 4 例（50\%）は有 効で投与直後あるいは $1 \sim 2$ 日のらちに著明に回復し ている．有効群と無効群を比較すると，一定の傾向が 見られる。すなわち徐々に発症する血栓症は側副血行 が豊富で症状も中等症以下のことが多く容易に改善す る(症例 1，2，3).突然発症する塞栓症特に重症例は, 高齢者が多かったことも影響していると思われるが, 効果は思わしくなかった(症例 $6,7,8)$ ．しかしもち ろん以上の傾向は絶対的なものではない，症例 4 は心 房細動等合併症はないが高度の麻疸が突発し塞栓症も 疑われるが症状は著明に改善して招り，逆に症例 5 の 様に血栓症でも血管の動脈硬化性変化が著しい場合に は再閉塞のため一気に悪化することもありうる，その 中で症例 3 は本療法の最も良い適応となる症例の一つ と思われる， $\mathrm{C}_{1}, \mathrm{C}_{2}$ 部の狭窄は約 $75 \%$ と比較的軽度で ありながら中等度の症状があり, 狭窄の進展とともに さらに悪化する可能性が充分あったが，UK 投与によ り未然に防ぐことができたと考兄られる。また小川

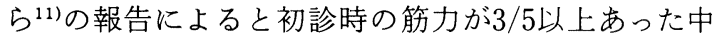
大脳動脈閉塞症（計79例）でも約 $80 \%$ はある程度の麻 痺は残存したとしており，これらの軽症例の回復を著 しく促進すると考兄られる。一方塞栓症を多く含む重 症例は有効例がなく出血性梗塞の可能性も考光あわせ ると本療法の適応の有無は問題となろら。

あらためて本療法の適応を考えると，その効果と副 作用の両面からの検討が必要と考兄られる。まず効果 を予測するためには病態に拈ける血栓の関与の程度と 虚血による脳損傷の程度の双方を評価しなければなら ない，虚血の大部分は血栓が関与しているが，脂肪塞 栓等もあり全例が血栓溶解療法の適応となるわけでは ないまた血管自体の変化が大きく再開通後も高度の 狭窄が残存することがまれならず認められる。

脳の損傷の程度つまり可逆性か否かの問題が最も重 要と思われる，血行再建を試みている報告み見ると， 発症よりの時間を強調するものが多(、4)12)が，虚血の 程度がより重要な因子である。 Jones ら ${ }^{13)}$ はこのふた つの要素を $\mathrm{X}, \mathrm{Y}$ 軸にとり，明瞭に示している，来院 時に時間の要素を判断することは容易であるが，残存 血流量あるいは代謝の変化の程度を的確にしかも短時 間のうちに測定することは現在のところ困難である。 しかしそれが可能になれば，再開通による効果だけで なく著名な脳浮腫や出血性梗塞という副作用の発現の 可能性の評価が容易となり，より厳密な適応決定が行 なわれることになろう。さらに現在研究されている barbiturate, mannitol ${ }^{14) 15)}$, naloxone ${ }^{16)}$ 等脳保護剤が 改良実用化されれば，本療法を含めた急性期血行再建 術の適応はさらに拡大されるものと考光られる。

一方副作用に扮いて最も問題となるのは頭蓋内出血 であり，これには主に血管，血液，血圧が関与してい る。脳血管特に穿通枝に壊死性の変化があり，それが 新鮮な血栓によって修復されている場合等には，UK の直接作用により出血が若起されることも考えられ る.しかし実際に血管損傷の面で最も問題となるのは 虚血により血管内皮が影響を受け，再開通に際し出血 する出血性梗塞である．特に塞栓症では神経細胞及び 血管組織が不可逆的変化を起こした後に自然再開通が 起き，致命的な出血性梗塞に移行することが知られて いる，UKを投与し再開通の時期を早めることにより 重篤な出血性梗塞を予防することも期待されるが，逆 に助長する可能性もあり, やはり症例の選択が重要と 考えられる，ところが現在一般に行なわれているCT では発症の $1 \sim 2$ 日後にならないと出血性梗塞への移 
行は予測できない. MR は CT より早期に（3〜6時 間後 ${ }^{17) 18)}$ 変化を捉えられると言われ, 症例 6 でも 1 時 間後はやや不明瞭な, 6 時間後には明らかな所見が認 められた。 今後 dynamic CT P MRI, SPE CT P PET による超急性期の研究が必要となろら.

次に UK 投与時の血液の变化に於いては fibrinogen と $\alpha_{2} \mathrm{AP}$ の減少が最も問題となろう. fibrinogenは凝 固系の第 1 因子でその減少により止血が抑制されるの は明らかである。 fibrin を分解する plasmin の特異的 inhibitorである $\alpha_{2} \mathrm{AP}$ の減少がさらに加わればでき た fibrin は直ちに分解され血栓は生じにくくなる，血 管の破綻部位がない限り出血することはないはずであ るが前述のような部位があり一旦出血すると大出血に なる可能性は大きい。この意味で確かに fibrinogen の 減少は一つの欠点かと思われるが, 逆に血栓周囲の $\alpha_{2}$ $\mathrm{AP}$ 濃度の低下は血栓溶解にとって不可欠な条件と考 兄られ, 今後は fibrinogenを減少させずに線溶能を高 めることが課題となり t-PA や scu-PAの検討が待た れる. しかしこのような血液の変化は比較的短期間で 回復する. UK の半減期は数分間 ${ }^{1920)}$ であり, plasmin も $\alpha_{2} \mathrm{AP}$ が完全に中和されていないかぎり不活化さ れるので, 投与後数時間から24時間の観察を行な兄ば, 特殊な場合をのぞきその後に出血することは稀と考学 られる. 現在では既に, 心筋梗塞, 深部静脈血栓症に 対し96万単位程度の UK（あるいは streptokinase）の 投与はかなり行なわれているが脳出血の合併は稀であ りZ Zeumerらも諸家の報告 ${ }^{21223)}$ から $1 \%$ 以下であろ らと述べている。また少数報告されている線溶療法中 に起きた頭蓋内出血の症例をみると, いずれも抗凝固 剂を同時に使用しているが，UK 単独でも充分効果は 得られるのでへパリンの併用はさけるべきと考学られ る.

UK は直接 fibrin を分解するわけではなく, 前述の $\alpha_{2} \mathrm{AP}$ や plasminogen の濃度の影響を強く受けるた めに, 血栓溶解療法における至適血中濃度も明らかで はない，高田ら ${ }^{24)}$ とよると，クエン酸採血による血浆 に, $\mathrm{Ca}^{2+}$, thrombin, UKを加兄て行なった in vitro の実験では, UK $100 \mathrm{U} / \mathrm{m} l$ の場合に 10 分前後で急激に $\mathrm{FDP}$ が上昇するのに対し, $\mathrm{UK} 10 \mathrm{U} / \mathrm{m} l$ の場合には $\alpha_{2}$ $\mathrm{AP}$ 存在下では短時間に FDP は出現して来ない.これ から推測すると数十単位 $/ \mathrm{m} l$ の濃度で, 数十分間血栓 に接触することが必要と考えられる。循環血浆量を $3,000 \mathrm{~m} l$ と仮定し単純に計算すると, 12 万単位の投与 で $40 \mathrm{U} / \mathrm{m} l$ となるが，このレベルを数十分維持するた
めには24 96万単位を10４0分程度かけて投与する必 要があると思われる。ただしこれは全身投与として考 えた場合であり，血栓の近くに動注すればその量も減 少させることができると思われる。症例 6 は $6.3 \mathrm{U} / \mathrm{m} l$ と低い值を示したが，これは 48 万単位を 40 分と比較的 ゆっくりと投与ししかも投与終了10分後に採血したた めと考えられる。

結局のところ, 疾患の性質及び UK の血液に拈よぼ す効果と副作用の可能性を考え合わせると, 長時間あ るいは数日にわたるUK の投与は好ましくなく, 超急 性期に中等量を短期間に使用し, 後に必要に応じて抗 凝固剂や抗血小板投与を考慮すべきと考兄られる.

今回は症例数が 8 例と少なく, control 群がないが, 本療法の有効例の殆どは UK 投与直後の血管撮影中 にその効果が認められることから, 自然再開通が偶然 にその時に起きたとは考学にくく，UKが再開通を促 進したことは間違いのないところと考えられる。適応 となるのは脳梗塞症例全例から見ると少数ではある が, これといった有効な治療法のない現在, 試みるべ き治療法であると考えられる。また症状が軽いと穿通 枝梗塞であろうとして見逃される場合が多いと思われ るが発症後 $5 \sim 6$ 時間以内の症例は軽症でも積極的に 血管撮影を行ない本療法を試みるべきと思われる。

\section{結 語}

1 : 発症後 5 時間以内の脳主幹動脈狭窄及び閉塞症 8 例に対し UK を動脈内投与し，その効果及び副作用 につき検討した。

$2: 50 \%$ の 例は著効を示し, 特に軽症, 中等症の 血栓症は良い適応と考えられた。

3 : 症例 6 のような重症塞栓症は出血性梗塞の危険 性があり, UK 投与前に残存血流量あるいは脳組織や 血管組織の損傷の程度を評価することが必要と考えら れる。

$4:$ 本療法は 3 のような場合をのぞき出血による重 篤な合併症を若起する可能性は少ないと考えられる。

5 : UK は, 数十万単位 (24 96万単位) 数十分か けて（投与量に応じ 1 時間以内）に投与し，原則とし て翌日以降の追加投与打よびへパリン等抗凝固剤の併 用は避けるべきと考兄られる。

最後に症例を提供して頂いた新城市民病院脳神経外科村 木正明先生, 聖隷浜松病院脳神経外科外山香澄先生, 聖隷三 方原病院脳神経外科堺常雄先生に謝意を表します。また血 液所見につき種々の御指導を頂いた浜松医科大学第 2 生理 
学教室高田明和教授, さらに御校閲頂いた浜松医科大学脳 神経外科植村研一教授に深謝致します。

\section{文 献}

1) Herndon RM, Nelson JN, Johnson JF, et al : Thrombolytic treatment in cerebrovascular thrombosis. In Macmillan RL, Mustard JF (eds): Anticoagulants and Fibronolysins. Lea and Febiger (Philadelphia), 1961, pp154-164

2) Meyer JS, Gilroy J, Barnhart ME, et al : Therapeutic thrombolysis in cerebral thromboembolism : Randomized evaluation of intravenous streptokinase. In Millikan $\mathrm{CH}$, Siekert RG, Whisnant JP (eds): Cerebral Vascular Disease, Fourth Prinston Conference. Grune and Stratton (New York), 1965, pp200-213

3) Fletcher AP, Alkjaersig N, Lewis M, et al: A pilot study of urokinase therapy in cerebral infarction. Stroke 7 : 135-146, 1976

4) del Zeppo GJ, Zeumer H, Harker LA, et al: Thrombolytic therapy in stroke: Possibilities and hazards. Stroke 17 : 595-607, 198607, 1986

5）鎮目研吾, 植村研一, 高田由美子, 高田明和, 西川 方夫，半田 肇：脳梗塞に対するウ口キナーゼ療 法. 血液と脈管 $18: 391-393,1987$

6) Tsushima N, Koike A, Nakayama R: The effects of urokinase on microcircuration and hemorheology. In Tsuchiya M, et al : Microcirculation Annual 1985, Amsterdam, Excerpta Medica, 1985, pp37-45

7) Zeumer $\mathrm{H}$ : Survey of progress: Vascular recanalizing techniques in interventional neuroradiology. J Neurol 231 : 287-294, 1985

8) Nenci GG, Gresele P, Tarameli $M$, et al : Thrombolytic therapy for thromboembolism of vertebrobasilar artery. Angiology $34: 561-571$, 1983

9）荒木 功, 松永守雄, 小川修一ら：頝部および頭蓋 内脳主幹動脈閉塞急性期症例に対するウロキナー ゼ局所動注の経験. 脳神経外科 13：465-471, 1985

10) Verstraete M, Collen D: Thrombolytic therapy in the eighties. Blood $67: 1529-1541,1986$

11）小川 彰, 鈴木二郎：脳梗塞急性期症例の予後. 日 独医報 $29: 578-589,1984$
12) Zeumer H, Hündgen R, Ferbert A, et al : Local intraarterial fibrinolytic therapy in inaccessible internal carotid occlusion. Neuroradiology 26 : 315-317, 1984

13) Jones TH, Morawetz RB, Crowell RM, et al : Thresholds of focal cerebral ischemia in awake monkeys. J Neurosurg 54: 773-782, 1981

14) Suzuki J, Yoshimoto $T$, Kodama N : A new therapeutic method for acute brain infarction: Revasculization following the administration of mannitol and perfluorochemicals-A preliminary report. Surg Neurol 17 : 325-332, 1982

15) Meyer FB, Anderson RE, Sundt TM, et al : Treatment of experimental focal cerebral ischemia with mannitol. J Neurosurg 66: 109 $-115,1987$

16) Adams HP, Olinger CP, Barsan WG, et al : A dose-escalation study of naloxone for treatment of patients with acute cerebral ischemia. Stroke $17: 404-409,1986$

17) Mano I, Levy RM, Crooks LE, et al: Proton nuclear magnetic resonance imaging of acute experimental cerebral ischemia. Invest Radiol $18: 345-351,1980$

18）山形 専, 菊池晴彦, 伊原郁夫ら：脳梗塞急性期の MRI. 神経外科 26:677-682, 1986

19）上野連雄：ウロキナーゼの代謝と作用機序に関す る研究. J Med Enzymol 1:86-91, 1975

20）若山雄次：Urokinase の Radioimmunoassay と 血中 UK 動態．血液と脈管 $7: 1085-1088,1976$

21) Aldrich MS, Sherman SA, Greenberg HS: Cerebrovascular complications of streptokinase infusion. JAMA 253 : 1777-1779, 1985

22) Rutsch W, Schartl M, Mathey D, et al: Percutaneous transluminal coronary recanalization: Procedure, results, and acute complications. Am Heart J 102: 1178-1181, 1981

23) Martin M: Thrombolytic therapy in arterial thromboembolism. Prog Cardiovasc Dis XXI(5) : 351-374, 1979

24) Takada A, Watahiki Y, Takada Y : Effects of fibrin on the enhanced activation of plasminogen by urokinase and tissue plasminogen activator: Role of cross-link. Thrombos Res $41: 605-613,1986$ 


\title{
Abstract \\ Intra-arterial urokinase infusion in the very early stage of cerebral artery occlusion and stenosis at their main trunks
}

\author{
Kengo Shizume, M.D. \\ Department of Neurosurgery, Hamamatsu University School of Medicine
}

Eight patients, aged 43 78 years, with occlusion or stenosis of intracranial cerebral arteries at their main trunks were treated with intraarterial urokinase infusion within 5 hours after onset. Intracranial hemorrhage was excluded and low density area were absent on the first CT examination. Three of eight patients were diagnosed as embolism because of the sudden onset and coexisted atrial fibrillation. Middle cerebral artery (MCA) occlusion was disclosed in 5 cases. MCA stenosis, internal carotid artery (ICA) occlusion and ICA stenosis were revealed in each one case by angiography. $24 \sim 72 \times 10^{4}$ units of urokinase was infused manually into the common or internal carotid artery through the catheter for angiography within 10 50 minutes. Anticoagulants were not used exept in one case.

Four patients were immediately improved after urokinase infusion and discharged without any significant sequelae. Patients with mild or moderate disability due to thrombosis recovered and those with severe symptoms due to embolism scarcely improved. The follow-up CT scans revealed hemorragic infarction in only one case (embolism of MCA), although symptoms did not deteriorate.

After infusion of $48 \times 10^{4}$ units of urokinase for 50 minutes, fibrinogen and $\alpha_{2}$-antiplasmin $\left(\alpha_{2} \mathrm{AP}\right)$ decreased to $34 \%$ and $21 \%$ of the original values, respectively. Although the decrease of fibrinogen level is a disadvantage in this therapy, the decrease in the level of $\alpha_{2}$ AP near the clot is probably indispensable for the fibrinolytic effect. If the endothelial damage of ischemic arteries still remain mild and reversible, hemorrhagic complication after reperfusion may rarely take place. It is suggested that intraarterial urokinase infusion is a relatively safe and effective therapy of cerebral artery occlusion and stenosis in strictly selected cases.

(Jpn. J. Stroke 10: 85-93, 1988) 